\title{
Beyond Depression, Anxiety and Posttraumatic Stress Disorder Symptoms: Qualitative Study of Negative Emotional Experiences in Hematopoietic Stem Cell Transplant Patients
}

Running Title: Negative Emotional Experiences in HSCT

Hermioni L. Amonoo, MD, MPP ${ }^{1,2,3}$, Lydia A. Brown, PhD ${ }^{4}$, Carlyn F. Scheu, BS 5 , Lauren E. Harnedy, BA $^{5}$, William F. Pirl, MD, MPH ${ }^{1,2}$, Areej El-Jawahri, MD²,6, Jeff C. Huffman, MD ${ }^{2,5}$

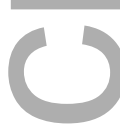

${ }^{1}$ Dana-Farber Cancer Institute, Department of Psychosocial Oncology, Boston, Massachusetts ${ }^{2}$ Harvard Medical School, Boston, Massachusetts

${ }^{3}$ Brigham and Women's Hospital, Department of Psychiatry, Boston, Massachusetts

${ }^{4}$ University of Melbourne, Melbourne School of Psychological Sciences, Melbourne, Australia

${ }^{5}$ Massachusetts General Hospital, Department of Psychiatry, Boston, Massachusetts

${ }^{6}$ Massachusetts General Hospital, Department of Hematology and Oncology, Boston, Massachusetts

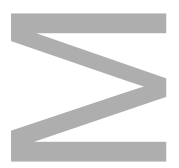

\section{Corresponding Author Information:}

Hermioni Lokko Amonoo, MD, MPP

60 Fenwood Rd, $4^{\text {th }}$ Floor

Boston, MA 02115

Phone: (617) 732-4241

e-mail: hermioni_lokko@dfci.harvard.edu

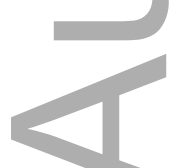

Conflicts of Interest: All authors have no financial relationships with commercial or corporate interest in connection with the work submitted to report.

This is the author manuscript accepted for publication and has undergone full peer review but has not been through the copyediting, typesetting, pagination and proofreading process, which may lead to differences between this version and the Version of Record. Please cite this article as doi: $\underline{10.1111 / \text { ECC. } 13263}$

This article is protected by copyright. All rights reserved 
Funding. Time for development and completion of this work were funded by the Harvard Medical School Dupont-Warren Research Fellowship Award (to HA), Harvard Medical School Livingston Research Award (to HA) and grant 1-17-ICTS-099 from the American Diabetes Association and NIDDK R21DK109313 from the National Institutes of Health (to JH).

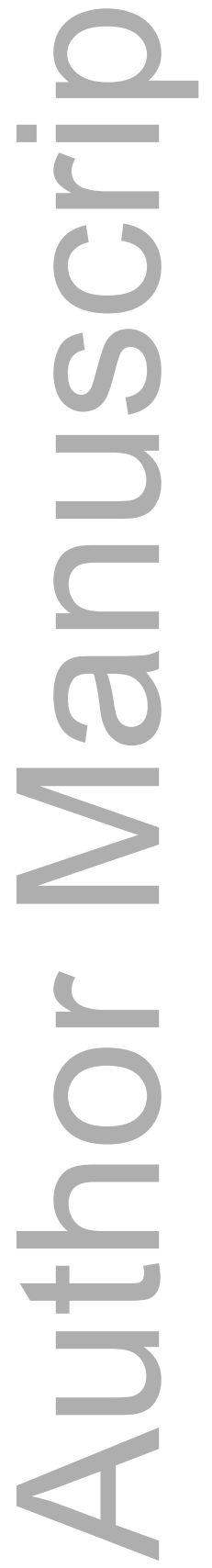




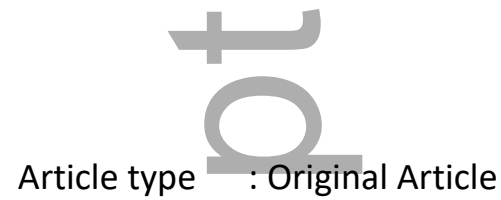

Article type : Original Article

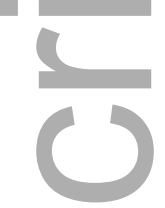

\title{
Beyond Depression, Anxiety and Posttraumatic Stress Disorder Symptoms: Qualitative Study of Negative Emotional Experiences in Hematopoietic Stem Cell Transplant Patients
}

\begin{abstract}
$\underline{\text { Abstract }}$
Objective: Psychological distress impacts a variety of health outcomes in hematopoietic stem cell transplantation (HSCT). Focused qualitative studies on a wider range of psychological distress in HSCT patients are lacking. However, understanding the subtleties of psychological distress (e.g., fear, guilt, loss of control) in HSCT patients is imperative to optimizing the psychological well-being of this vulnerable population. To explore psychological distress after transplantation, we conducted semi-structured interviews with $25 \mathrm{HSCT}$ patients.
\end{abstract}

Methods: Interviews were completed in the first 100 days after transplantation. Interview modules explored psychological distress symptoms in the hospital and during the first 100 days after HSCT, along with the perceived impact of these symptoms on their recovery.

Results: Of the negative emotional experiences reported, feeling trapped, fear, guilt, discouragement, and powerlessness were frequently expressed. Patients reported that negative emotional states interfered with their motivation to participate in health behaviors important to the transplant recovery.

Conclusion: As one of the few qualitative studies broadly characterizing the nature of negative emotional experiences after HSCT, these findings add to our understanding of the specific psychological challenges in this growing patient population and can inform development of targeted interventions and overall management of psychological distress during HSCT recovery.

$\underline{\text { Keywords. }}$ Cancer, psychological, psychosocial oncology, negative emotional states, hematopoietic stem cell transplant, quality of life 


\section{Introduction}

Hematopoietic stem cell transplantation (HSCT) is a life-saving treatment for many patients with hematologic malignancies (Singh \& McGuirk, 2016). Currently, approximately 20,000 HSCTs are performed in the United States annually and the number of transplants is projected to increase (Majhail et al., 2013). Survival following HSCT continues to improve with a decreased burden of physical symptoms and complications that follow the transplant. Psychological well-being is critical to successful recovery from HSCT due to the intense nature of the treatment during hospitalization and the demands of quarantine and frequent follow-up visits (Mosher, Redd, Rini, Burkhalter, \& DuHamel, 2009).

Psychological well-being during HSCT recovery is usually threatened by multiple factors including rehospitalization, graft vs. host disease (GVHD), infections, and mandatory isolation while the immune system reconstitutes (Amonoo, Barclay, et al., 2019; Costanzo, Juckett, \& Coe, 2013). Low levels of psychological well-being characterized by symptoms of depression, anxiety, posttraumatic stress disorder (PTSD) is prevalent (e.g., depression [35\%], PTSD symptoms [20\%]) (Amonoo, Massey, et al., 2019). These well-studied psychiatric symptoms significantly and negatively impact a variety of health outcomes in this population. For example, depression is associated with decreased health-related quality of life (QOL), poorer functioning and increased mortality (Loberiza et al., 2002; Mosher et al., 2011); and PTSD is associated with QOL deficits, and increased depression. (Mosher et al., 2009)

Despite the high prevalence of the negative psychological symptoms in the HSCT population, most HSCT patients do not meet criteria for a psychiatric diagnosis (Amonoo, Barclay, et al., 2019). The deep understanding of the impact of depression, anxiety and PTSD has resulted in targeted interventions for HSCT patients that improve health outcomes (El-Jawahri et al., 2016). However, we know that a variety of negative emotional experiences (e.g., shame(Dolezal \& Lyons, 2017), guilt(Day \& Bobocel, 2013), external locus of control(Nazareth et al., 2016), and fear(Page-Reeves et al., 2013)) which are not frequently assessed in medical populations as compared to depression and anxiety, negatively impacts health-related outcomes. As in a diverse group of medical populations, many HSCT patients continue to suffer with various psychological distress symptoms, and not all psychological distress is the same and the nature of the distress should inform management. Our understanding of psychological distress in HSCT patients must go beyond commonly studied symptoms that are typically measured quantitatively with self-assessment measures. Qualitative studies that explore the breadth of psychological distress beyond depression, anxiety, and PTSD symptoms in HSCT patients are lacking. Hence, we used semi- 
structured qualitative interviews to explore the negative psychological experiences during their acute recovery from HSCT.

\section{Methods}

\section{Study Criteria and Recruitment}

We have previously reported full details about study design, procedures and analysis (Amonoo, Brown et al., 2019), and include brief details below. We used a qualitative research design and hour-long, semi-structured qualitative interviews to explore the negative emotional experiences of HSCT patients in the first 100 days of transplantation. Adult patients with hematologic malignancies hospitalized for allogeneic HSCT at an academic cancer center were eligible to participate in the study. Between September 2017 and December 2017, we approached eligible patients during their inpatient transplant hospitalization, recruited and enrolled participants into the study after written informed consent. We excluded patients who could not speak English, had an active psychiatric diagnosis (e.g., schizophrenia, substance use disorder) as diagnosed by the Mini International Neuropsychiatric Interview (MINI(Pinninti, Madison, Musser, \& Rissmiller, 2003)) or had cognitive deficits (assessed with a six-item cognitive screen(Callahan, Unverzagt, Hui, Perkins, \& Hendrie, 2002)) that would interfere with their ability to provide informed consent or engage in study procedures. We followed the consolidated criteria for conducting and reporting qualitative research (COREQ) guidelines (Tong, Sainsbury, \& Craig, 2007). This research was conducted following all guidelines of the Declaration of Helsinki. The study was approved by our center's Institutional Review Board.

\section{Patient Characteristics and Baseline Assessment}

While participants' inpatient transplantation hospitalization lasted approximately 20-30 days, demographic information was obtained via self-report at enrollment and baseline (mean of 12 days after transplantation). The Hospital Anxiety and Depression Scale (HADS) (Bjelland, Dahl, Haug, \& Neckelmann, 2002), a 14-item validated questionnaire, was used to measure symptoms of anxiety and depression at baseline and follow-up (mean of 100 days after transplantation). The cutoff score for the

depression subscale (HADS-D) was $\geq 8$ and that of the anxiety subscale (HADS-A) was $\geq 8$. (Zigmond \& Snaith, 1983) Prior to the follow-up assessment at approximately a 100 days post transplantation, participants were required to follow-up twice weekly and then weekly as outpatients.

\section{Qualitative Interviews}

A trained psychiatrist (HA), with no prior relationship with participants, conducted semistructured interviews at the end of their hospitalization and approximately 100 days after transplantation. Interviews explored patients' negative emotional experiences associated with their illness and HSCT 
recovery. Baseline interviews (between September 2017 and February 2018) were conducted in person prior to patient discharge from the transplant hospitalization while the majority of follow-up interviews (between December 2017 and May 2018) conducted via phone. Interviews were recorded, transcribed verbatim and uploaded to QSR NVivo 12 software (QSR International, Melbourne, Australia) for analysis. Specific topics explored by interviews included the range, intensity, and timing of negative psychological experiences in the context of illness and HSCT recovery, and the impact of negative experiences on daily life.

\section{Data Analysis}

Qualitative Analysis

Directed content analysis, a descriptive approach to qualitative data analysis (Vaismoradi, Turunen, \& Bondas, 2013) was used to analyze the data. In consultation with qualitative research experts and the senior author (JH), two a psychiatrist (HA) and a clinical psychologist (LB)] developed the codebook, prior to independently coding all interviews between July 2018 and October 2018. Our interview guide and qualitative data informed the development of the codebook. We modified the codebook after reading a small proportion of the transcripts to test the codes. The unit of coding was a complete sentence. Emerging themes from the codes were discussed during weekly team meetings, during which discrepancies were adjudicated to ensure that the themes reflected the original data. Inter-rater reliability of coding $(\kappa=0.92)$ was high. We reached thematic saturation with a sample size of 25 patients (consistent with similar studies (El-Jawahri et al., 2017; Saunders et al., 2018) at baseline and 21 patients follow-up.

\section{Descriptive statistics analysis}

The population's demographics and HADS were described using descriptive statistics (mean, standard deviation).

\section{Demographics}

\section{$\underline{\text { Results }}$}

Of 36 approached patients, two were ineligible due to limited English proficiency and severity of illness, nine declined and 25 (71\% of potentially eligible participants) ultimately enrolled. Figure 1 provides further details about patient enrollment. At follow-up, 21 participants (84\%) completed the interviews. Table 1 shows baseline participant characteristics. Participants had a mean age of 50.4 (SD 14.2), $44 \%$ were women, $60 \%$ were married, and $80 \%$ were White. Acute myeloid leukemia (44\%) was the most common hematologic malignancy, unrelated and matched unrelated donors were the most common transplants and most (84\%) participants did not have acute GVHD. Participants did not meet criteria for clinically significant depression or anxiety symptoms based on the HADS scores as showed in Table 2 . 


\section{Negative Psychological Experiences}

Participants reported a breadth of negative emotional experiences at both time points. At baseline, common themes of negative emotional experiences included that of feeling a lack of control over their illness and treatment, guilt about burdening family to care for them during the HSCT recovery, fear of death, and feeling overwhelmed by the transition from hospital to home. At follow-up, common themes of negative emotional experiences included frustration with limited physical function and fear of cancer recurrence. A report of feeling trapped by the required isolation either in the hospital or at home was common at both time points. We highlight the negative emotional experiences reported by patients below. Table 3 provides a detailed summary of themes of negative emotional experiences described by participants.

\section{Guilt}

Participants reported guilt about their response to treatment or the impact of their illness and treatment on their family. Guilt was also reported about good recovery when none of the complications anticipated by the clinical team were experienced:

"I'm almost feeling guilty that I don't feel the way they said." (ID 5)

Guilt was also expressed about the perceived burden imposed on family and loved ones by the level of support that recovery from the transplant and the routine follow-up entailed:

"So I have a little bit of guilt as far as the burden, the burden that I was going to put on my family so quickly." (ID 19)

\section{Feeling Trapped}

Participants consistently reported they felt trapped by various aspects of the transplantation process and the recovery. During hospitalization, allogeneic recipients are quarantined in their rooms for most of the admission, leading to substantial impingement on their activities. One patient articulates:

"Either way, you do feel like you're trapped and there's nowhere to go and the rooms are small." (ID 10)

Some participants at follow-up reported that the isolative aspects of recovery outside the hospital, such as restrictions from visiting crowded places, limitations on travel especially travel by plane, and having to wear masks was distressing:

"I just wanna be able to go outside without masks on and just be normal. I want to be able to travel, we travel a lot usually. And just the limitations of feeling trapped in my local area I don't like." (ID 7)

\section{Fear}


Fear was explicitly reported, especially at baseline, about cancer recurrence, complications, and inability to return to baseline level of functioning. One participant reported that the transplantation and being in the hospital caused more heightened fear of cancer recurrence than he has experienced in the past:

"Tremendous fear that the cancer would come back." (ID 16)

Several participants at both baseline and at follow-up also reported increased fear of dying than they had experienced prior to the transplant:

"Yeah, because I feel afraid of dying a lot more" (ID 8)

\section{Discouragement}

Despite the promise of cure offered by HSCT, participants reported feeling discouraged about the uncertainty of their treatment response or their chances of remission after the transplant at baseline and especially at follow-up in the setting of some complications and worsening physical symptoms. One participant articulates:

"And I don't know what those chances [of remission] are, so that's pretty discouraging to me right now” (ID 1)

Although most HSCT recipients go into the transplant with awareness of the potential physical limitations that the recovery entails due to fatigue, the quarantine status, and isolation, several participants reported discouragement about their physical limitations that negatively impacted their psychological well-being. One participant at follow-up reported:

"Yeah... I have the energy to do certain things up to a point. So that's discouraging too sometimes, ... getting too tired quick." (ID 3)

\section{Powerlessness and Lack of Control}

Some patients reported that the transplant process and recovery is overwhelming in ways they did not anticipate prior to their transplant. The feeling of powerlessness and lack of control was consistently reported more at follow-up than baseline. One participant describes:

"This is much harder than I thought it was going to be. I did not expect it to be so difficult to feel so powerless" (ID 16)

Closely related to feeling powerless is the sense of feeling out of control over the treatment outcome, and physical functioning in a way that some participants felt was underestimated prior to the transplant. One participant states:

“...Feel like you have no control over your bodily functions and you're being potty trained again, and that's kind of disturbing." (ID 25) 


\section{Relationships between Negative Emotional Experiences and Health Behaviors}

A relationship between negative emotional experiences and health behaviors was reported by several participants at both time points. Negativity in general, was associated with decreased motivation for meaningful activities and reduced physical activity. Several participants reported noting a connection between a negative emotional state and willingness to engage in health behaviors, including self-care and physical activity:

"I think when you focus on the negative, you tend to feel drained. So it's easier to take a nap than it is to unroll your yoga mat." (ID 2)

"If you're feeling negative, you kind of just want to sleep all day and not really do much." (ID 17)

Participants also reported that negativity fueled hopelessness, apathy and disengagement with healthy behaviors and care:

"Yeah. If you feel sad you're kind of, not quitting on yourself, but kind of giving up, I think." (ID 5)

"Yes, when you are not feeling great, you just disengage." (ID 14)

\section{Discussion}

We used semi-structured interviews and qualitative analysis to explore psychological distress in 25 allogeneic HSCT recipients at an academic cancer institution during the first 100 days of the recovery from HSCT. Prior studies in this area have used primarily cross-sectional quantitative methods or selfreport questionnaires and have focused on depression, anxiety and PTSD symptoms without exploring negative emotional experiences broadly. To our knowledge, this is one of few focused studies that are qualitative in nature and explored a broad range of negative psychological states in this population (Xuereb \& Dunlop, 2003). Not all psychological distress is the same and interventions that target distress should be tailored to the specific type of distress. Hence, a comprehensive understanding of the psychological distress beyond those commonly assessed via self-report questionnaires (e.g., HADS) in hematologic cancer patients will help HSCT clinicians better identify and manage distress in this population. Patients readily reported a variety of negative emotional experiences (e.g., feelings of powerlessness or a challenged locus/sense of control regarding their illness and treatment, guilt about the burden placed on their caregivers due to intensive follow-up requirements and frequent hospital visits following the transplant, feeling trapped in the setting of the required quarantine status) although patients did not meet criteria for clinically significant depression or anxiety based on their HADS scores. This emphasizes the need for alternate ways of distress assessment in addition to validated measures of distress in the HSCT population. 
Feelings of powerlessness and feeling trapped were prominent themes articulated by many patients in our cohort. Prior studies in cancer populations have highlighted patients' frustration with feeling powerless as they recover from their cancer and treatment (Baqutayan, 2012; Knapp, Marziliano, \& Moyer, 2014). More so than other medical populations, for HSCT patients, a sense of powerlessness may be especially heightened due to the added restriction and needed isolation as patients reconstitute their immune system (Xuereb \& Dunlop, 2003). While our cohort highlighted the distress that accompanies feelings of powerlessness over their health in the first 100 days, the feeling of powerlessness can persist longer in survivorship (Baker, Zabora, Polland, \& Wingard, 1999).

Closely linked to powerlessness is guilt reported by a portion of our sample. Prior studies have highlighted a high prevalence of guilt in lung cancer patients compared to those with breast or prostate cancer due to lung cancer patients' attribution to smoking as the cause of their cancer (Dirkse et al., 2014; LoConte, Else-Quest, Eickhoff, Hyde, \& Schiller, 2008). Guilt is also prevalent in solid organ transplant survivors, especially as it pertains to survivor's guilt where patients express guilt that they survived while their donor did not (Zimmermann, Pabst, Bertram, Schiffer, \& de Zwaan, 2016). Compared to solid organ transplantations where donors mostly do not survive their donation, HSCT donation is not typically accompanied by the death of the donor (Perez-San-Gregorio et al., 2017). It was notable to observe that guilt expressed in our cohort was more focused on loss of independence and control, and feeling like a burden to family and caregivers. Guilt in our cohort like many cancer survivors has also been reported in the context of survivors comparing their lives to others with similar diseases and treatment trajectories who have died from the experience.(Glaser, Knowles, \& Damaskos, 2019) For example, in a study aimed to understand survivor guilt in 108 lung cancer survivors by Perloff et al., 64\% of participants scored above the mean on the survivor guilt scale and a report of the death of others was one of the five recurring themes underlying survivor guilt.(Perloff, King, Rigney, Ostroff, \& Johnson Shen, 2019) Despite the limited evidence of effective interventions to address guilt, brief psychotherapeutic interventions that highlight cognitive restructuring of the sources of guilt could be emphasized by HSCT clinicians in the acute recovery (Perloff, King, Rigney, Ostroff, \& Johnson Shen, 2019).

Fear, an acute and intense emotional reaction to a specific and present danger (Davis, 1998), has been increasingly studied in medical populations, including cancer patients (Reed et al., 2019; Sarkar, 2014). Similar to the findings of prior studies, our cohort expressed a fear of relapse or transplant failure (Baker et al., 1999). Among medical populations, fear is more prevalent in cancer populations partly due to the uncertainty regarding treatment efficacy and relapse (Sharpe, Curran, Butow, \& Thewes, 2018). Although the risk of relapse in the HSCT population is less than those in patients who fail conventional treatment but do not receive HSCT, the risk of relapse or secondary malignancies remains significant (Barrett \& Battiwalla, 2010; Bomken \& Skinner, 2015). Fear can be debilitating and undermine patients' 
ability to cope and function (Bevans, Mitchell, \& Marden, 2008), and most concerningly interfere with adherence to recommendations for optimal recovery. Hence, fear should be explored explicitly especially during the first 100 days of the transplant when the risk of complications is highest.

There is a robust literature on the negative association between negative psychological states and health behaviors in many medical populations (Hardcastle et al., 2015). However, our understanding of the impact of negative psychological states beyond depression, anxiety and PTSD in HSCT patients is limited. Most participants reported that feeling negative hindered their ability to stay motivated and engage with their treatment, consistent with other findings about negative states and engagement in care in other populations (Bogner \& McClintock, 2016; Fiske, Wetherell, \& Gatz, 2009; Unutzer \& Park, 2012). This further underscores the need for HSCT clinicians to understand the wide range of psychological distress symptoms in this population in order to effectively determine the best targeted interventions to address distress.

This study was limited by several factors. The sample was mostly non-Latino White, married, educated and were recruited from a tertiary academic medical center, limiting the generalizability of our findings. Our sample size was small $(\mathrm{N}=25)$ but allowed for thematic saturation. Different types of HSCTs are accompanied with varying amount of psychological distress due to the differences in symptom burden, complications and recovery needs. Hence, with our sample including only allogeneic recipients, other HSCT recipients, including autologous recipients, may report different negative experiences. With $70 \%$ of potentially eligible patients enrolling in the study, selection bias was likely not a prominent factor, although patients who elected to participate in the study may have been more psychologically-minded than those who declined to participate. Finally, as majority of participants did not meet criteria for clinically significant depressive symptoms or anxiety based on their HADS score, we did not categorize qualitative data based on HADS scores although patients with clinically significant depressive or anxiety symptoms could likely have more intense negative emotional experiences than those who did not.

In conclusion, assessing for psychological distress beyond depression, anxiety and PTSD is warranted in the HSCT population, especially since most of these patients do not meet diagnostic criteria for psychiatric disorders. HSCT clinicians should partner with mental health clinicians, especially consultation-liaison psychiatrists to comprehensively assess, explore and manage the psychological distress in acute transplant recovery. Our study highlights that HSCT patients (even those who do not meet criteria for a mood disorder on a self-report measure such as the HADS) experience a variety of distress symptoms (e.g., guilt, powerlessness and fear) which have varying impact on the recovery, function and quality of life throughout HSCT recovery. One size does not fit all, hence, a comprehensive understanding of the nature of distress in HSCT patients will inform the development of targeted interventions that effectively address psychological distress in this population. 


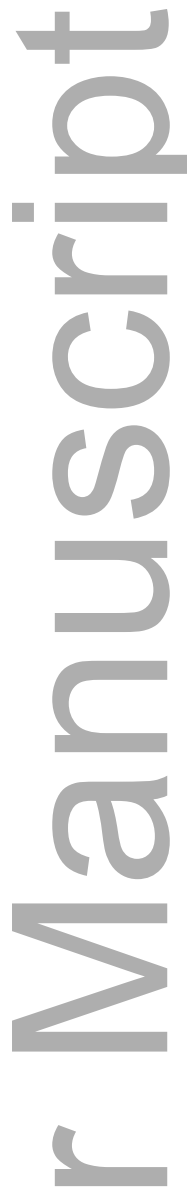

\section{References}

Amonoo, H. L., Barclay, M. E., El-Jawahri, A., Traeger, L. N., Lee, S. J., \& Huffman, J. C. (2019). Positive Psychological Constructs and Health Outcomes in Hematopoietic Stem Cell Transplantation Patients: A Systematic Review. Biol Blood Marrow Transplant, 25(1), e5-e16. doi: 10.1016/j.bbmt.2018.09.030

Amonoo, H. L., Brown, L. A., Scheu, C. F., Millstein, R. A., Pirl, W. F., Vitagliano, H. L., . . Huffman, J. C. (2019). Positive Psychological Experiences in Allogeneic Hematopoietic Stem Cell Transplantation. Psychooncology. doi: 10.1002/pon.5128

Amonoo, H. L., Massey, C. N., Freedman, M. E., El-Jawahri, A., Vitagliano, H. L., Pirl, W. F., \& Huffman, J. C. (2019). Psychological Considerations in Hematopoietic Stem Cell Transplantation. Psychosomatics. doi: 10.1016/j.psym.2019.02.004 
Baker, F., Zabora, J., Polland, A., \& Wingard, J. (1999). Reintegration after bone marrow transplantation. Cancer Pract, 7(4), 190-197.

Baqutayan, S. M. (2012). The effect of anxiety on breast cancer patients. Indian J Psychol Med, 34(2), 119-123. doi: 10.4103/0253-7176.101774

Barrett, A. J., \& Battiwalla, M. (2010). Relapse after allogeneic stem cell transplantation. Expert Rev Hematol, 3(4), 429-441. doi: 10.1586/ehm.10.32

Bevans, M. F., Mitchell, S. A., \& Marden, S. (2008). The symptom experience in the first 100 days following allogeneic hematopoietic stem cell transplantation (HSCT). Support Care Cancer, 16(11), 1243-1254. doi: 10.1007/s00520-008-0420-6

Bjelland, I., Dahl, A. A., Haug, T. T., \& Neckelmann, D. (2002). The validity of the hospital anxiety and depression scale. An updated literature review. Journal of Psychosomatic Research, 52(2), 69-77.

Bogner, H. R., \& McClintock, H. F. (2016). Costs of Coexisting Depression and Diabetes. J Gen Intern Med, 31(6), 594-595. doi: 10.1007/s11606-016-3675-5

Bomken, S., \& Skinner, R. (2015). Secondary Malignant Neoplasms Following Haematopoietic Stem Cell Transplantation in Childhood. Children (Basel), 2(2), 146-173. doi: 10.3390/children2020146

Callahan, C. M., Unverzagt, F. W., Hui, S. L., Perkins, A. J., \& Hendrie, H. C. (2002). Six-item screener to identify cognitive impairment among potential subjects for clinical research. Med Care, 40(9), 771-781. doi:10.1097/00005650-200209000-00007

Costanzo, E. S., Juckett, M. B., \& Coe, C. L. (2013). Biobehavioral influences on recovery following hematopoietic stem cell transplantation. Brain Behav Immun, 30 Suppl, S68-74. doi: 10.1016/j.bbi.2012.07.005

Davis, M. (1998). Are different parts of the extended amygdala involved in fear versus anxiety? Biol Psychiatry, 44(12), 1239-1247.

Day, M. V., \& Bobocel, D. R. (2013). The Weight of a Guilty Conscience: Subjective Body Weight as an Embodiment of Guilt. PLoS One, 8(7), e69546. doi:10.1371/journal.pone.0069546

Dirkse, D., Lamont, L., Li, Y., Simonic, A., Bebb, G., \& Giese-Davis, J. (2014). Shame, guilt, and communication in lung cancer patients and their partners. Curr Oncol, 21(5), e718-722. doi: $10.3747 /$ co.21.2034

Dolezal, L., \& Lyons, B. (2017). Health-related shame: an affective determinant of health? Med Humanit, 43(4), 257-263. doi:10.1136/medhum-2017-011186

El-Jawahri, A., LeBlanc, T., VanDusen, H., Traeger, L., Greer, J. A., Pirl, W. F., . . Temel, J. S. (2016). Effect of Inpatient Palliative Care on Quality of Life 2 Weeks After Hematopoietic Stem Cell

This article is protected by copyright. All rights reserved 
Transplantation: A Randomized Clinical Trial. JAMA, 316(20), 2094-2103. doi:

10.1001/jama.2016.16786

El-Jawahri, A., Traeger, L., Shin, J. A., Knight, H., Mirabeau-Beale, K., Fishbein, J., . . Temel, J. S. (2017). Qualitative Study of Patients' and Caregivers' Perceptions and Information Preferences About Hospice. J Palliat Med, 20(7), 759-766. doi: 10.1089/jpm.2016.0104

Glaser, S., Knowles, K., \& Damaskos, P. (2019). Survivor guilt in cancer survivorship. Soc Work Health Care, 58(8), 764-775. doi:10.1080/00981389.2019.1640337

Hardcastle, S. J., Hancox, J., Hattar, A., Maxwell-Smith, C., Thogersen-Ntoumani, C., \& Hagger, M. S. (2015). Motivating the unmotivated: how can health behavior be changed in those unwilling to change? Front Psychol, 6, 835. doi: 10.3389/fpsyg.2015.00835

Knapp, S., Marziliano, A., \& Moyer, A. (2014). Identity threat and stigma in cancer patients. Health Psychol Open, 1(1), 2055102914552281. doi: 10.1177/2055102914552281

Loberiza, F. R., Jr., Rizzo, J. D., Bredeson, C. N., Antin, J. H., Horowitz, M. M., Weeks, J. C., \& Lee, S. J. (2002). Association of depressive syndrome and early deaths among patients after stem-cell transplantation for malignant diseases. J Clin Oncol, 20(8), 2118-2126. doi:

10.1200/JCO.2002.08.757

LoConte, N. K., Else-Quest, N. M., Eickhoff, J., Hyde, J., \& Schiller, J. H. (2008). Assessment of guilt and shame in patients with non-small-cell lung cancer compared with patients with breast and prostate cancer. Clin Lung Cancer, 9(3), 171-178. doi: 10.3816/CLC.2008.n.026

Majhail, N. S., Tao, L., Bredeson, C., Davies, S., Dehn, J., Gajewski, J. L., . . Kuntz, K. M. (2013). Prevalence of hematopoietic cell transplant survivors in the United States. Biol Blood Marrow Transplant, 19(10), 1498-1501. doi: 10.1016/j.bbmt.2013.07.020

Mosher, C. E., DuHamel, K. N., Rini, C., Corner, G., Lam, J., \& Redd, W. H. (2011). Quality of life concerns and depression among hematopoietic stem cell transplant survivors. Support Care Cancer, 19(9), 1357-1365. doi: 10.1007/s00520-010-0958-y

Mosher, C. E., Redd, W. H., Rini, C. M., Burkhalter, J. E., \& DuHamel, K. N. (2009). Physical, psychological, and social sequelae following hematopoietic stem cell transplantation: a review of the literature. Psychooncology, 18(2), 113-127. doi: 10.1002/pon.1399

Nazareth, M., Richards, J., Javalkar, K., Haberman, C., Zhong, Y., Rak, E., . . van Tilburg, M. A. (2016). Relating Health Locus of Control to Health Care Use, Adherence, and Transition Readiness Among Youths With Chronic Conditions, North Carolina, 2015. Prev Chronic Dis, 13, E93. doi:10.5888/pcd13.160046

This article is protected by copyright. All rights reserved 
Page-Reeves, J., Niforatos, J., Mishra, S., Regino, L., Gingrich, A., \& Bulten, R. (2013). Health Disparity and Structural Violence: How Fear Undermines Health Among Immigrants at Risk for Diabetes. J Health Dispar Res Pract, 6(2), 30-47.

Perez-San-Gregorio, M. A., Martin-Rodriguez, A., Borda-Mas, M., Avargues-Navarro, M. L., Perez-Bernal, J., \& Gomez-Bravo, M. A. (2017). Coping Strategies in Liver Transplant Recipients and Caregivers According to Patient Posttraumatic Growth. Front Psychol, 8, 18. doi: 10.3389/fpsyg.2017.00018

Perloff, T,,King, J. C., Rigney, M., Ostroff, J. S., \& Johnson Shen, M. (2019). Survivor guilt: The secret burden of lung cancer survivorship. J Psychosoc Oncol, 1-13. doi:

10.1080/07347332.2019.1569191

Pinninti, N. R., Madison, H., Musser, E., \& Rissmiller, D. (2003). MINI International Neuropsychiatric Schedule: clinical utility and patient acceptance. Eur Psychiatry, 18(7), 361-364. doi:10.1016/j.eurpsy.2003.03.004

Reed, S. C., Bell, J. F., Miglioretti, D. L., Nekhlyudov, L., Fairman, N., \& Joseph, J. G. (2019). Relationships Between Fear of Cancer Recurrence and Lifestyle Factors Among Cancer Survivors. J Cancer Educ. doi: 10.1007/s13187-019-01509-2

Sarkar, S., Scherwath, A., Schirmer, L., Schulz-Kindermann, F., Neumann, K., Kruse, M., ... \& Koch, U. (2014). Fear of recurrence and its impact on quality of life in patients with hematological cancers in the course of allogeneic hematopoietic SCT. Bone marrow transplant, 49(9), 1217.

Saunders, B., Sim, J., Kingstone, T., Baker, S., Waterfield, J., Bartlam, B., . . Jinks, C. (2018). Saturation in qualitative research: exploring its conceptualization and operationalization. Qual Quant, 52(4), 1893-1907. doi: 10.1007/s11135-017-0574-8

Sharpe, L., Curran, L., Butow, P., \& Thewes, B. (2018). Fear of cancer recurrence and death anxiety. Psychooncology, 27(11), 2559-2565. doi: 10.1002/pon.4783

Singh, A. K., \& McGuirk, J. P. (2016). Allogeneic Stem Cell Transplantation: A Historical and Scientific Overview. Cancer Res, 76(22), 6445-6451. doi: 10.1158/0008-5472.CAN-16-1311

Tong, A., Sainsbury, P., \& Craig, J. (2007). Consolidated criteria for reporting qualitative research (COREQ): a 32-item checklist for interviews and focus groups. Int J Qual Health Care, 19(6), 349357. doi: $10.1093 /$ intqhc/mzm042

Unutzer, J., \& Park, M. (2012). Strategies to improve the management of depression in primary care. Prim Care, 39(2), 415-431. doi: 10.1016/j.pop.2012.03.010

Vaismoradi, M., Turunen, H., \& Bondas, T. (2013). Content analysis and thematic analysis: Implications for conducting a qualitative descriptive study. Nursing \& health sciences, 15(3), 398-405.

This article is protected by copyright. All rights reserved 
Xuereb, M. C., \& Dunlop, R. (2003). The experience of leukaemia and bone marrow transplant: searching for meaning and agency. Psychooncology, 12(5), 397-409. doi: 10.1002/pon.648

Zigmond, A. S., \& Snaith, R. P. (1983). The hospital anxiety and depression scale. Acta psychiatrica scandinavica, 67(6), 361-370.

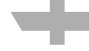

Zimmermann, T., Pabst, S., Bertram, A., Schiffer, M., \& de Zwaan, M. (2016). Differences in emotional responses in living and deceased donor kidney transplant patients. Clin Kidney J, 9(3), 503-509. doi: $10.1093 / \mathrm{ckj} / \mathrm{sfw} 012$

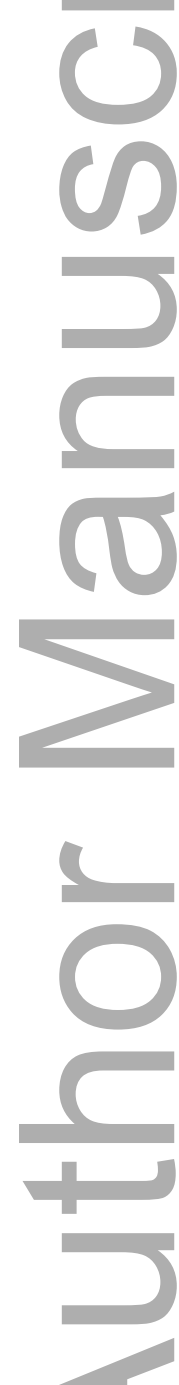

\section{Table 1. Participant Characteristics}

Age and Sex

Age (years; mean \pm standard deviation)

Women
$50.4 \pm 14.2$

$11(44)$ 
Race \& Ethnicity

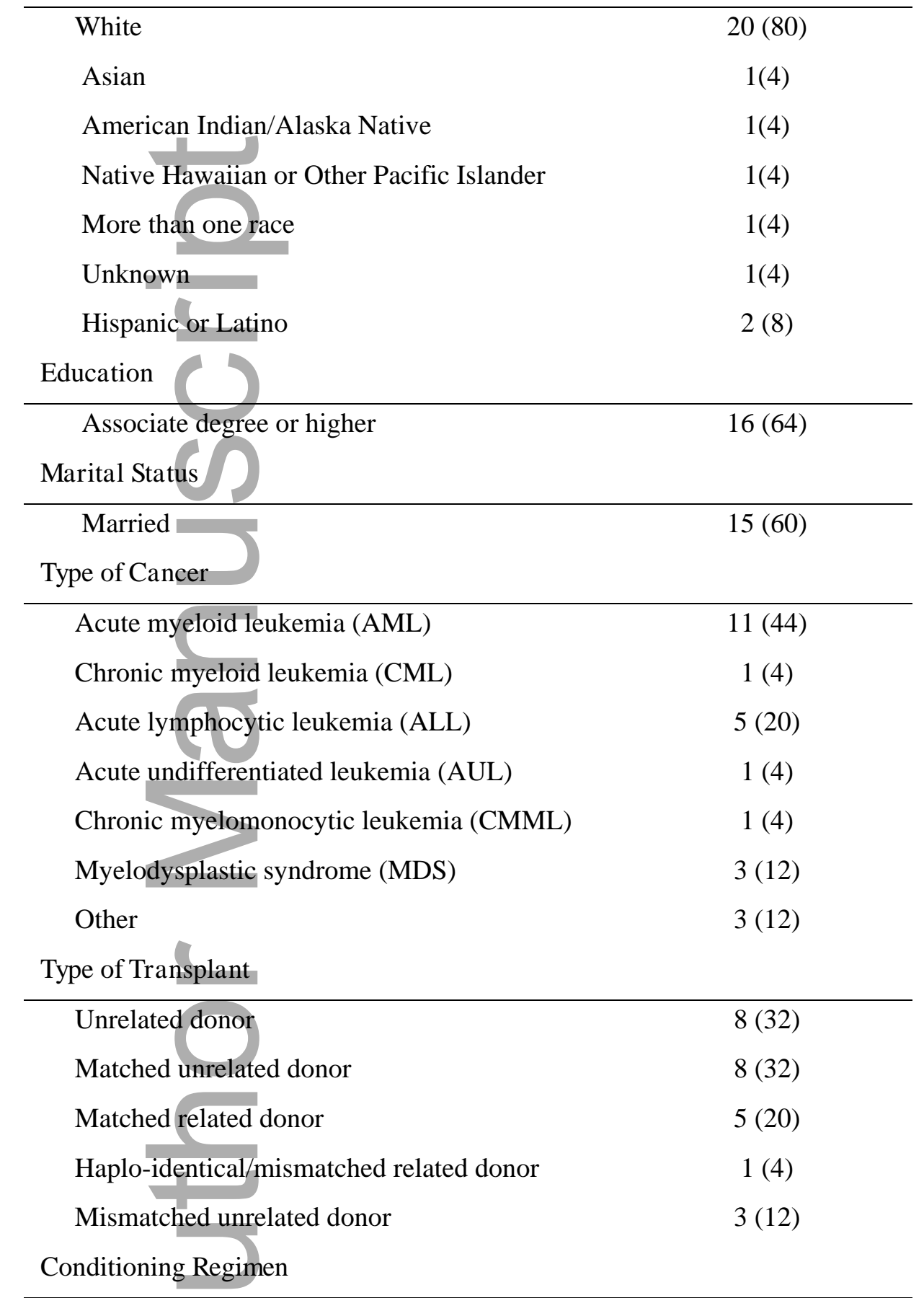

$\begin{array}{ll}\text { Reduced-intensity conditioning } & 5(20) \\ \text { Acute GVHD } & \text { in 100-days } \\ \text { Stem Cell Source } & 4(16)\end{array}$

Bone marrow transplant

$10(40)$

Peripheral blood stem cell transplant 14 (56) 


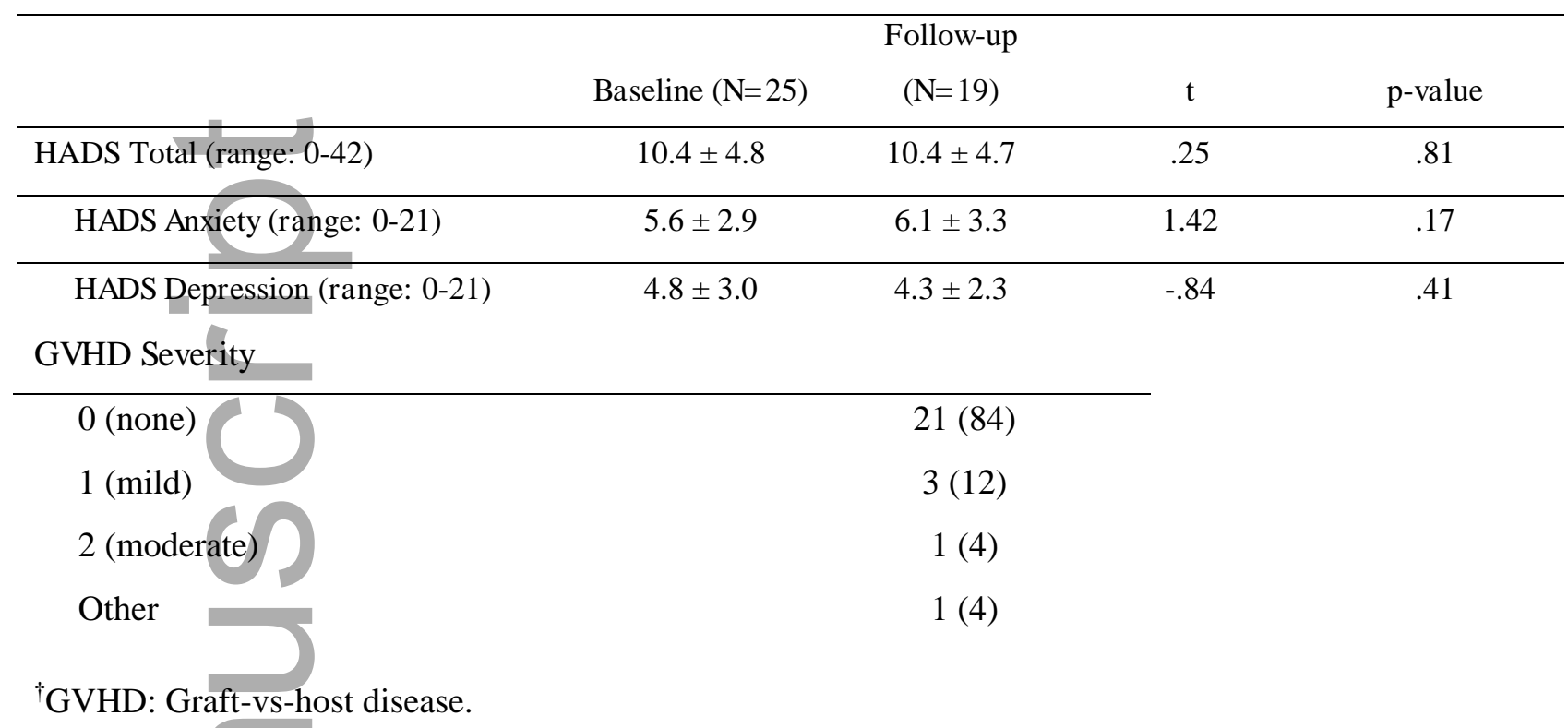

Table 2. Quantitative Assessment of Depression and Anxiety at Baseline and Follow-up 


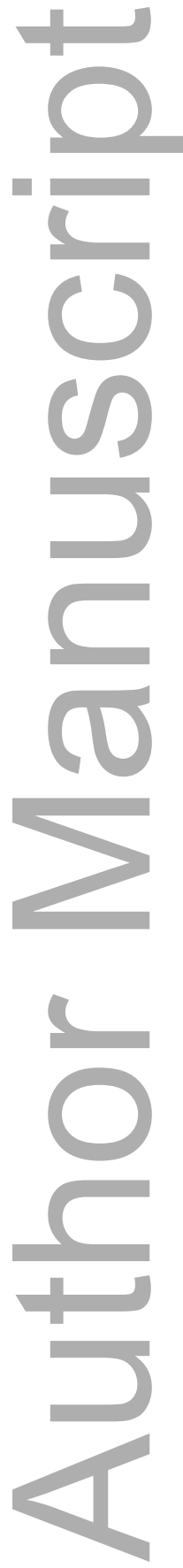

This article is protected by copyright. All rights reserved 
Table 3. Negative Emotional Experiences

\begin{tabular}{|c|c|c|}
\hline Theme & Sub-Theme & Quotes \\
\hline $\begin{array}{l}\text { Locus of } \\
\text { Control }\end{array}$ & Lack of control over illness & $\begin{array}{l}\text { "It's something you have no control over. Some people get a shitty hand. .. Just bad luck." } \\
\text { (ID 4). "I'm a guy who's always in control and this disease, you have no control." (ID 5) } \\
\text { "...Feel like you have no control over your bodily functions and you're being potty trained } \\
\text { again, and that's kind of disturbing" (ID 25) }\end{array}$ \\
\hline \multirow[t]{2}{*}{ Guilt } & Guilt about burden on family & $\begin{array}{l}\text { "So I have a little bit of guilt as far as the burden, the burden that I was going to put on my } \\
\text { family so quickly." (ID 19) }\end{array}$ \\
\hline & Guilt about no physical complications & "I'm almost feeling guilty that I don't feel the way they said." (ID 5) \\
\hline $\begin{array}{l}\text { Feeling } \\
\text { Overwhelmed }\end{array}$ & $\begin{array}{l}\text { Overwhelmed by transition from hospital } \\
\text { to home }\end{array}$ & $\begin{array}{l}\text { "And I think going from the hospital to home, although it's been a positive change, I just } \\
\text { kind of get overwhelmed." (ID 2) }\end{array}$ \\
\hline Frustration & Frustrated with limited physical function & $\begin{array}{l}\text { "So it's frustrating on that part... I mean, I can go, not very far, but I can go a distance } \\
\text { walking with them for a little while." (ID 6). "It's frustrating to have to rethink what you } \\
\text { do every second of the day and not to be able to go out, make things happen, do things. } \\
\text { That's frustrating." (ID 11) }\end{array}$ \\
\hline \multirow[t]{2}{*}{ Depression } & $\begin{array}{l}\text { Impact of depression on interaction with } \\
\text { family }\end{array}$ & "I couldn't even Facetime with them [family] because I was so depressed" (ID 7) \\
\hline & Depression due to less physical activity & $\begin{array}{l}\text { "I've been a little bit kind of depressed. But I mean, a lot of it's kind of being more so kind } \\
\text { of less active." (ID 4) }\end{array}$ \\
\hline $\begin{array}{l}\text { Feeling } \\
\text { trapped/Social }\end{array}$ & Feeling trapped by hospitalization & $\begin{array}{l}\text { "Either way, you do feel like you're trapped and there's nowhere to go and the rooms are } \\
\text { small" (ID 7) }\end{array}$ \\
\hline
\end{tabular}

This article is protected by copyright. All rights reserved 


\begin{tabular}{|c|c|c|}
\hline isolation & Feeling trapped by the required isolation & $\begin{array}{l}\text { "I just wanna be able to go outside without masks on and just be normal...I want to be } \\
\text { able to travel, we travel a lot usually. And just the limitations of feeling trapped in my } \\
\text { local area I don't like." (ID 7) }\end{array}$ \\
\hline \multirow[t]{2}{*}{ Fear } & Fear of death & "Yeah, because I feel afraid of death a lot more" (ID 8) \\
\hline & ear of cancer recurrence & "Tremendous fear that the cancer would come back" (ID 16) \\
\hline Sadness & dness about decreased physical function & $\begin{array}{l}\text { "And there were periods of time, weeks, when I just-- I can't move. I've no energy. I don't } \\
\text { have enough energy to read, which makes me very sad." (ID 16) }\end{array}$ \\
\hline \multirow[t]{4}{*}{ Anxiety } & $\begin{array}{l}\text { Anxiety about leaving the house in the } \\
\text { setting of immune system recovery post- } \\
\text { transplant }\end{array}$ & $\begin{array}{l}\text { "Unless my numbers were okay. But even when they were okay, I would still get a little } \\
\text { nervous going out." (ID 17) }\end{array}$ \\
\hline & Anxiety in the setting of transition to home & $\begin{array}{l}\text { Because I think when you are in treatment, you're just so focused on getting your } \\
\text { treatments and that day and what's happening that day, that when you're done and you're } \\
\text { home and everything is done and basically that's it, you kind of just have nothing else to } \\
\text { focus on except every little ache and pain and ruminate on things like that, and so it just } \\
\text { gives you anxiety. (ID 17) }\end{array}$ \\
\hline & Anxiety about reduced restrictions & $\begin{array}{l}\text { "Well, I've just been anxious to getting back to being allowed to do things. I mean my } \\
\text { body has been progressing so my mind is saying, "Okay, I feel great," but I don't want to } \\
\text { jinx anything, but for the most part following the doctor's regulations and requests and } \\
\text { restrictions." (ID 22) }\end{array}$ \\
\hline & Worry about family & $\begin{array}{l}\text { "I felt more worried about them [family] than myself [inaudible] because like I said, I'm } \\
\text { an only child so-- I definitely have a close relationship to both my parents." (ID 4) }\end{array}$ \\
\hline Disappointment & Disappointment about physical limitations & $\begin{array}{l}\text { "Well, I'm disappointed I can't do the things that I'm used to doing, but I've kind of taken } \\
\text { on projects or things that I should've done a long time ago." (ID 1) }\end{array}$ \\
\hline Discouragement & Discouragement about uncertainty of & "And I don't know what those chances [of treatment] are, so that's pretty discouraging to \\
\hline
\end{tabular}

This article is protected by copyright. All rights reserved 


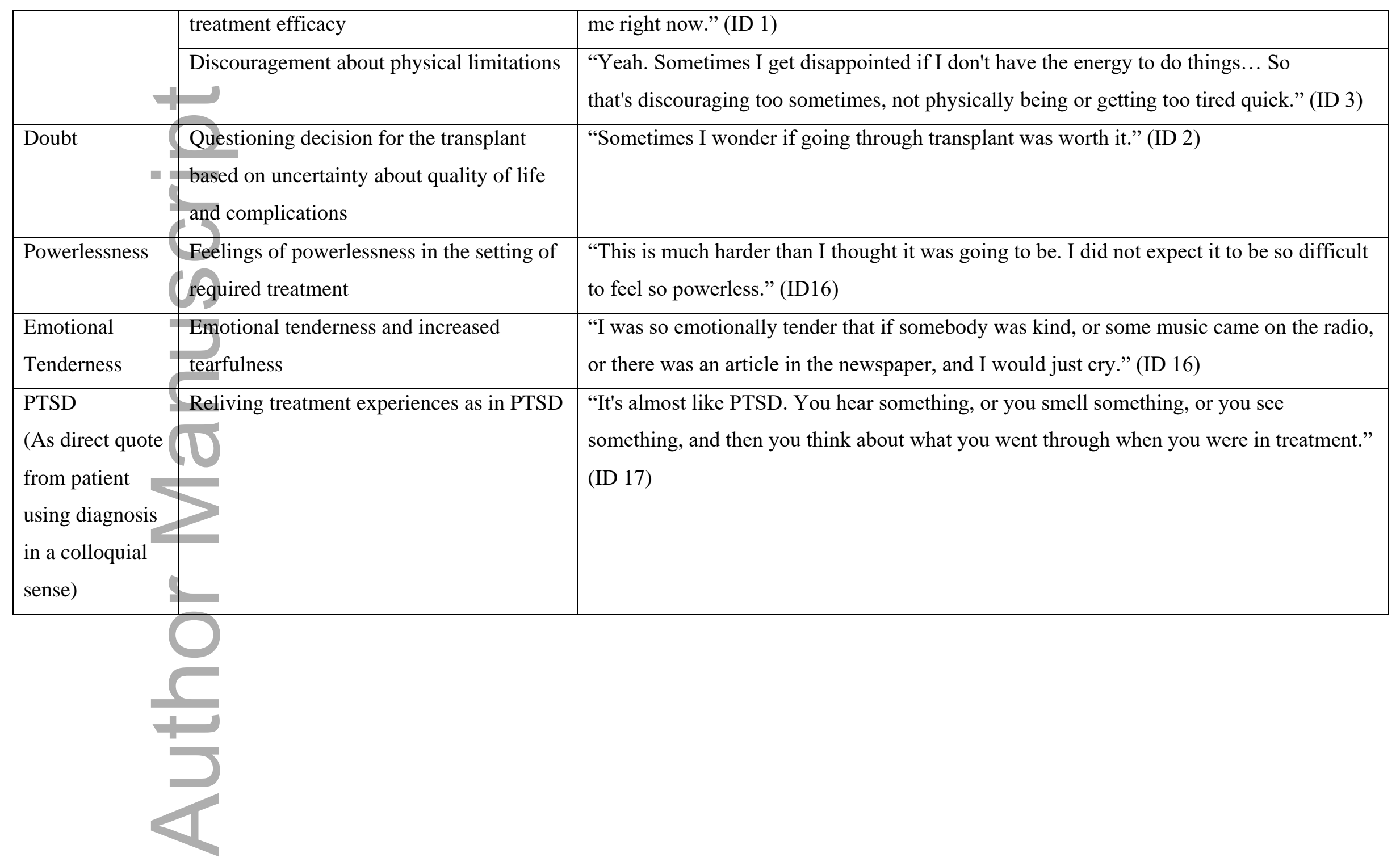

This article is protected by copyright. All rights reserved 


\section{Table 1. Participant Characteristics}

Age and Sex

\begin{tabular}{|c|c|}
\hline Age (years; mean \pm standard deviation) & $50.4 \pm 14.2$ \\
\hline $\begin{array}{c}\text { Women } \\
\text { Race \& Ethnicity }\end{array}$ & Race \& Ethnicity \\
\hline White & $20(80)$ \\
\hline Asian & $1(4)$ \\
\hline American Indian/Alaska Native & $1(4)$ \\
\hline Native Hawaiian or Other Pacific Islander & $1(4)$ \\
\hline More than one race & $1(4)$ \\
\hline Unknown & $1(4)$ \\
\hline Hispanic or Latino & $2(8)$ \\
\hline \multicolumn{2}{|l|}{ Education } \\
\hline \multicolumn{2}{|l|}{ Marital Status } \\
\hline \multicolumn{2}{|l|}{ Type of Cancer } \\
\hline Acute myeloid leukemia (AML) & $11(44)$ \\
\hline Chronic myeloid leukemia (CML) & $1(4)$ \\
\hline Acute lymphocytic leukemia (ALL) & $5(20)$ \\
\hline Acute undifferentiated leukemia (AUL) & $1(4)$ \\
\hline Chronic myelomonocytic leukemia (CMML) & $1(4)$ \\
\hline Myelodysplastic syndrome (MDS) & $3(12)$ \\
\hline Other & $3(12)$ \\
\hline \multicolumn{2}{|l|}{ Type of Transplant } \\
\hline Unrelated donor & $8(32)$ \\
\hline Matched unrelated donor & $8(32)$ \\
\hline Matched related donor & $5(20)$ \\
\hline Haplo-identical/mismatched related donor & $1(4)$ \\
\hline Mismatched unrelated donor & $3(12)$ \\
\hline \multicolumn{2}{|l|}{ Conditioning Regimen } \\
\hline Reduced-intensity conditioning & $5(20)$ \\
\hline
\end{tabular}




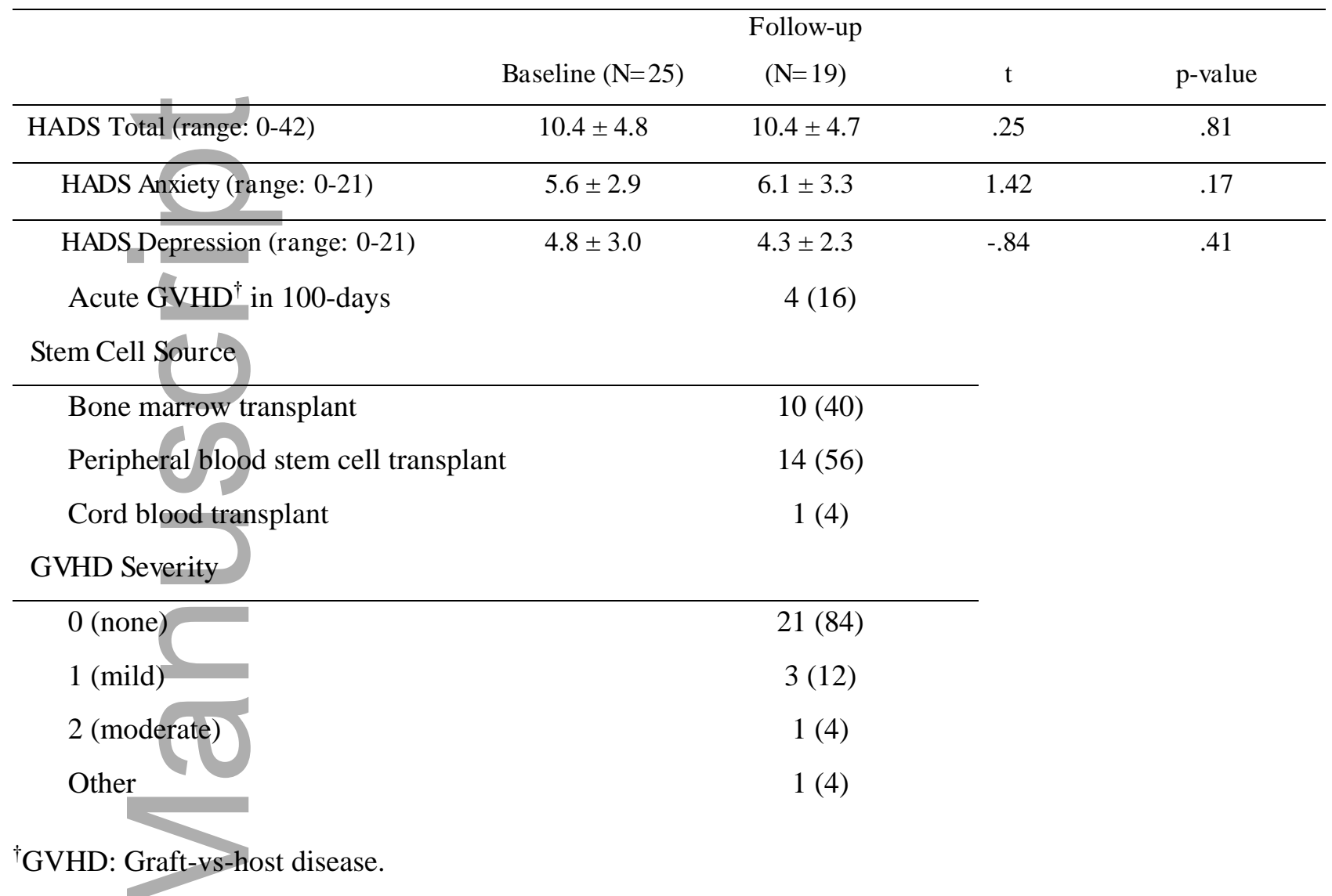

Table 2. Quantitative Assessment of Depression and Anxiety at Baseline and Follow-up

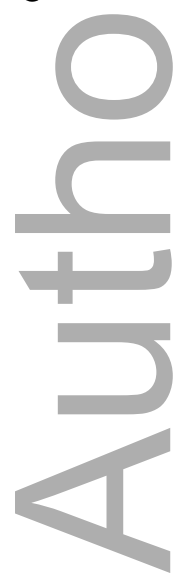

This article is protected by copyright. All rights reserved 


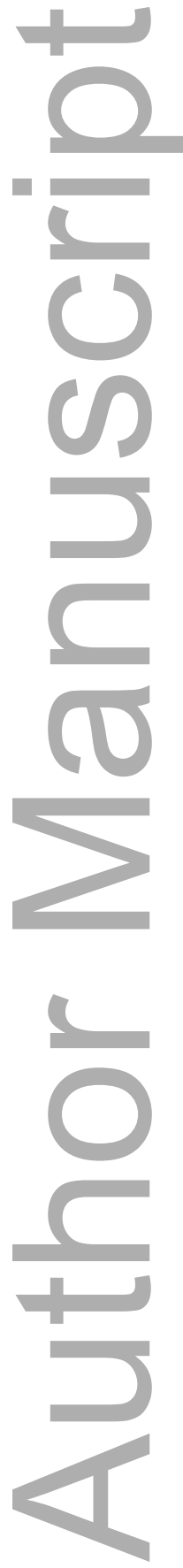

This article is protected by copyright. All rights reserved 
Table 3. Negative Emotional Experiences

\begin{tabular}{|c|c|}
\hline Sub-Theme & Quotes \\
\hline Lack of control over illness & $\begin{array}{l}\text { "It's something you have no control over. Some people get a shitty hand. .. Just bad luck." } \\
\text { (ID 4). "I'm a guy who's always in control and this disease, you have no control." (ID 5) } \\
\text { “...Feel like you have no control over your bodily functions and you're being potty trained } \\
\text { again, and that's kind of disturbing" (ID 25) }\end{array}$ \\
\hline Guilt about burden on family & $\begin{array}{l}\text { "So I have a little bit of guilt as far as the burden, the burden that I was going to put on my } \\
\text { family so quickly." (ID 19) }\end{array}$ \\
\hline Guilt about no physical complications & "I'm almost feeling guilty that I don't feel the way they said." (ID 5) \\
\hline \begin{tabular}{l|l} 
Feeling & Overwhelmed by transition from hospital \\
Overwhelmed & to home
\end{tabular} & $\begin{array}{l}\text { "And I think going from the hospital to home, although it's been a positive change, I just } \\
\text { kind of get overwhelmed." (ID 2) }\end{array}$ \\
\hline \begin{tabular}{l|l} 
Frustration & Frustrated with limited physical function
\end{tabular} & $\begin{array}{l}\text { "So it's frustrating on that part... I mean, I can go, not very far, but I can go a distance } \\
\text { walking with them for a little while." (ID 6). "It's frustrating to have to rethink what you } \\
\text { do every second of the day and not to be able to go out, make things happen, do things. } \\
\text { That's frustrating." (ID 11) }\end{array}$ \\
\hline $\begin{array}{l}\text { Impact of depression on interaction with } \\
\text { family }\end{array}$ & "I couldn't even Facetime with them [family] because I was so depressed" (ID 7) \\
\hline Depression due to less physical activity & $\begin{array}{l}\text { "I've been a little bit kind of depressed. But I mean, a lot of it's kind of being more so kind } \\
\text { of less active." (ID 4) }\end{array}$ \\
\hline Feeling trapped by hospitalization & $\begin{array}{l}\text { "Either way, you do feel like you're trapped and there's nowhere to go and the rooms are } \\
\text { small" (ID 7) }\end{array}$ \\
\hline
\end{tabular}

This article is protected by copyright. All rights reserved 


\begin{tabular}{|c|c|c|}
\hline $\begin{array}{l}\text { Feeling } \\
\text { trapped/Social } \\
\text { isolation }\end{array}$ & Feeling trapped by the required isolation & $\begin{array}{l}\text { "I just wanna be able to go outside without masks on and just be normal...I want to be } \\
\text { able to travel, we travel a lot usually. And just the limitations of feeling trapped in my } \\
\text { local area I don't like." (ID 7) }\end{array}$ \\
\hline Fear & Fear of death & "Yeah, because I feel afraid of death a lot more" (ID 8) \\
\hline & recurrence & "Tremendous fear that the cancer would come back" (ID 16) \\
\hline Sadness & Adness about decreased nhvsi & $\begin{array}{l}\text { "And there were periods of time, weeks, when I just-- I can't move. I've no energy. I don't } \\
\text { have enough energy to read, which makes me very sad." (ID 16) }\end{array}$ \\
\hline \multirow[t]{4}{*}{ Anxiety } & $\begin{array}{l}\text { Anxiety about leaving the house in the } \\
\text { setting of immune system recovery post- } \\
\text { ransplant }\end{array}$ & $\begin{array}{l}\text { "Unless my numbers were okay. But even when they were okay, I would still get a little } \\
\text { nervous going out." (ID 17) }\end{array}$ \\
\hline & nxiety in the setting of transition to home & $\begin{array}{l}\text { Because I think when you are in treatment, you're just so focused on getting your } \\
\text { treatments and that day and what's happening that day, that when you're done and you're } \\
\text { home and everything is done and basically that's it, you kind of just have nothing else to } \\
\text { focus on except every little ache and pain and ruminate on things like that, and so it just } \\
\text { gives you anxiety. (ID 17) }\end{array}$ \\
\hline & nxiety about reduced restrictions & $\begin{array}{l}\text { "Well, I've just been anxious to getting back to being allowed to do things. I mean my } \\
\text { body has been progressing so my mind is saying, "Okay, I feel great," but I don't want to } \\
\text { jinx anything, but for the most part following the doctor's regulations and requests and } \\
\text { restrictions." (ID 22) }\end{array}$ \\
\hline & Worry about family & $\begin{array}{l}\text { "I felt more worried about them [family] than myself [inaudible] because like I said, I'm } \\
\text { an only child so-- I definitely have a close relationship to both my parents." (ID 4) }\end{array}$ \\
\hline Disappointme & Disappointment about physical limitations & $\begin{array}{l}\text { "Well, I'm disappointed I can't do the things that I'm used to doing, but I've kind of taken } \\
\text { on projects or things that I should've done a long time ago." (ID 1) }\end{array}$ \\
\hline
\end{tabular}

This article is protected by copyright. All rights reserved 


\begin{tabular}{|c|c|c|}
\hline \multirow[t]{2}{*}{ Discouragement } & $\begin{array}{l}\text { Discouragement about uncertainty of } \\
\text { treatment efficacy }\end{array}$ & $\begin{array}{l}\text { "And I don't know what those chances [of treatment] are, so that's pretty discouraging to } \\
\text { me right now." (ID 1) }\end{array}$ \\
\hline & scouragement about physical limitations & $\begin{array}{l}\text { "Yeah. Sometimes I get disappointed if I don't have the energy to do things... So } \\
\text { that's discouraging too sometimes, not physically being or getting too tired quick." (ID 3) }\end{array}$ \\
\hline Doubt & $\begin{array}{l}\text { Questioning decision for the transplant } \\
\text { based on uncertainty about quality of life } \\
\text { and complications }\end{array}$ & "Sometimes I wonder if going through transplant was worth it." (ID 2) \\
\hline Powerlessness & $\begin{array}{l}\text { Feelings of powerlessness in the setting of } \\
\text { required treatment }\end{array}$ & $\begin{array}{l}\text { "This is much harder than I thought it was going to be. I did not expect it to be so difficult } \\
\text { to feel so powerless." (ID16) }\end{array}$ \\
\hline $\begin{array}{l}\text { Emotional } \\
\text { Tenderness }\end{array}$ & $\begin{array}{l}\text { Emotional tenderness and increased } \\
\text { tearfulness }\end{array}$ & $\begin{array}{l}\text { "I was so emotionally tender that if somebody was kind, or some music came on the radio, } \\
\text { or there was an article in the newspaper, and I would just cry." (ID 16) }\end{array}$ \\
\hline $\begin{array}{l}\text { PTSD } \\
\text { (As direct quote } \\
\text { from patient } \\
\text { using diagnosis } \\
\text { in a colloquial } \\
\text { sense) }\end{array}$ & Reliving treatment experiences as in PTSD & $\begin{array}{l}\text { "It's almost like PTSD. You hear something, or you smell something, or you see } \\
\text { something, and then you think about what you went through when you were in treatment." } \\
\text { (ID 17) }\end{array}$ \\
\hline
\end{tabular}

This article is protected by copyright. All rights reserved 
Figure 1: Participant Enrollment
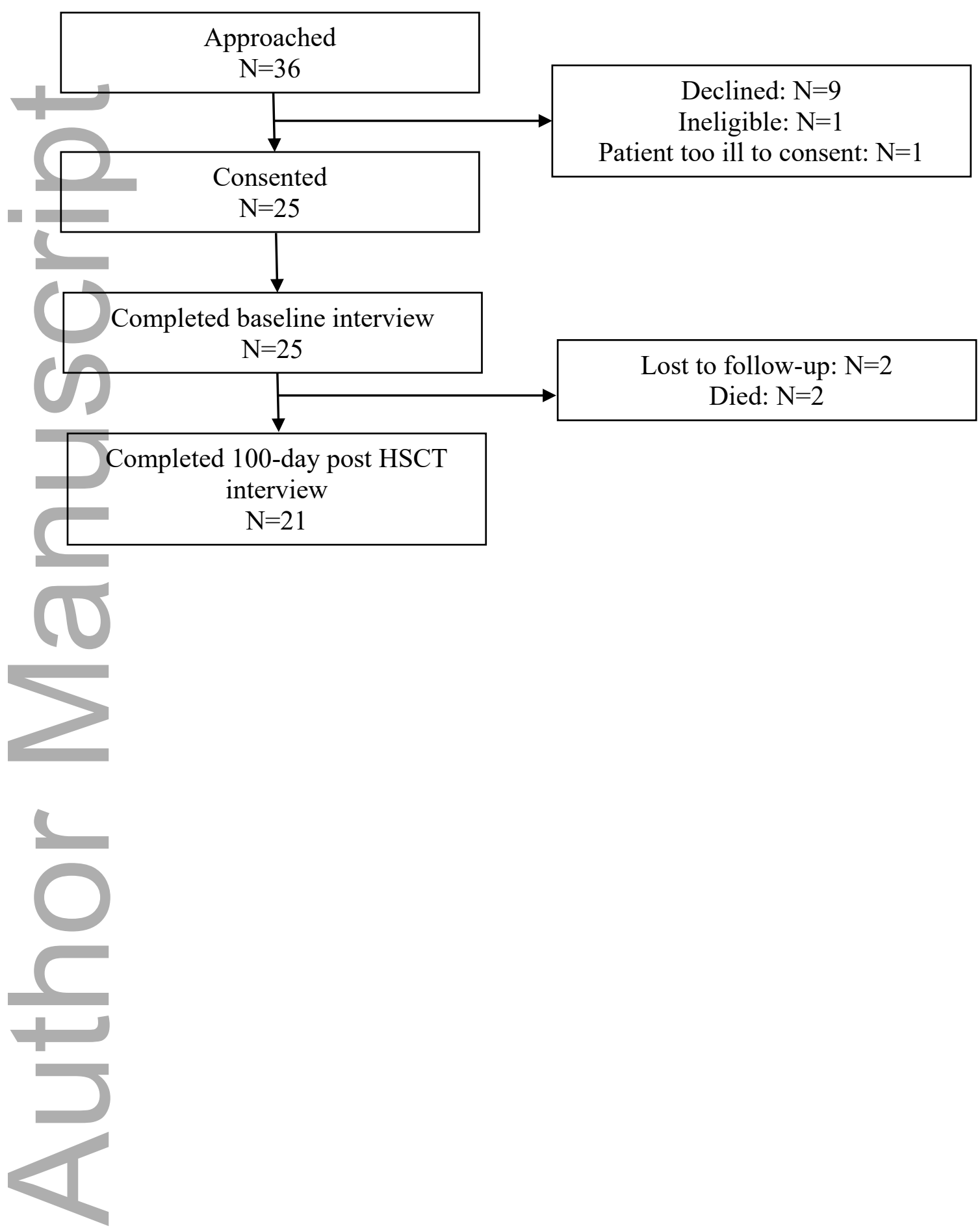


\section{University Library}

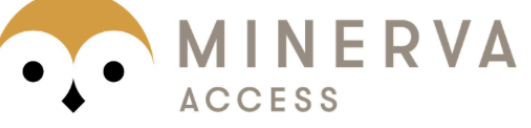

A gateway to Melbourne's research publications

Minerva Access is the Institutional Repository of The University of Melbourne

Author/s:

Amonoo, HL;Brown, LA;Scheu, CF;Harnedy, LE;Pirl, WF;El-Jawahri, A;Huffman, JC

Title:

Beyond depression, anxiety and post-traumatic stress disorder symptoms: Qualitative study of negative emotional experiences in hematopoietic stem cell transplant patients

Date:

2020-05-29

\section{Citation:}

Amonoo, H. L., Brown, L. A., Scheu, C. F., Harnedy, L. E., Pirl, W. F., El-Jawahri, A. \& Huffman, J. C. (2020). Beyond depression, anxiety and post-traumatic stress disorder symptoms: Qualitative study of negative emotional experiences in hematopoietic stem cell transplant patients. EUROPEAN JOURNAL OF CANCER CARE, 29 (5), https:// doi.org/10.1111/ecc. 13263 .

Persistent Link:

http://hdl.handle.net/11343/275792 